\title{
Penerapan Psak 109 Tentang Pelaporan Keungan Akuntansi Zakat, Infak/Sedekah Pada Masjid At-Taqwa Tempurejo
}

\author{
Novia Nurlailatul Qomar ${ }^{*}$, Yulinartati², Ari Sita Nastiti ${ }^{3}$ \\ 1,2,3Program Studi Akuntansi, Fakultas Ekonomi, Universitas Muhammadiyah Jember, Indonesia
}

\author{
A R T I C L E I N F O \\ Article history: \\ Received 19 May 2019 \\ Received in revised form \\ 16 June 2019 \\ Accepted 15 July 2019 \\ Available online 26 August \\ 2019 \\ Kata Kunci: \\ PSAK No. 109, Zakat \\ Laporan Keuangan, Infaq / \\ Sedekah Masjid \\ Keywords: \\ PSAK No. 109, Financial \\ Report Zakat, Infaq / Alms \\ Mosque
}

\begin{abstract}
A B S T R A K
Penelitian ini bertujuan untuk merekonstruksi laporan keuangan zakat, infaq / sedekah di Masjid At-Taqwa Tempurejo, sehingga dapat dilihat bagaimana laporan keuangan Masjid At-Taqwa Tempurejo dicatat dan memperkenalkan laporan keuangan zakat, infaq / sedekah. yaitu PSAK 109 untuk Takmir atau manajemen masjid. Penelitian ini menggunakan metode deskriptif yang dilakukan dengan observasi dan wawancara langsung dengan ketua takmir dan administrator masjid di At-Taqwa Tempurejo. Penelitian ini dimaksudkan untuk menggambarkan, menggambarkan atau menggambarkan kondisi dan gejala tertentu secara rinci yang terjadi di Masjid At-Taqwa Tempurejo, dan untuk memberikan gambaran umum tentang laporan keuangan zakat, infaq / sedekah masjid yang kemudian merekonstruksi laporan keuangan zakat, infaq / sedekah Taqwa Tempurejo sesuai dengan standar yang berlaku, yaitu PSAK 109 .. Transparansi dan akuntabilitas dalam laporan keuangan zakat, infaq / sedekah / sedekah dianalisis berdasarkan PSAK 109 yang terdiri dari lima komponen laporan keuangan yaitu laporan posisi keuangan, perubahan dalam laporan dana, aset yang dikelola, laporan arus kas, dan laporan keuangan
\end{abstract}

\section{A B S T R A C T}

This study aims to reconstruct the financial statements of zakat, infaq / alms at the At-Taqwa Tempurejo Mosque, so that it can be seen how the At-Taqwa Tempurejo Mosque financial report is recorded and introduces the financial statement of zakat, infaq / alms which is PSAK 109 to Takmir or mosque management. This study used a descriptive method which was carried out by observation and direct interview with the chairman of takmir and the mosque administrator at At-Taqwa Tempurejo. This study is intended to describe, describe or describe certain conditions and symptoms in detail that occur at the At-Taqwa Tempurejo mosque, and to provide an overview of the financial statements of zakat, infaq / mosque alms which then reconstruct financial statements of zakat, infaq / alms Taqwa Tempurejo in accordance with applicable standards, namely PSAK 109.. Transparency and accountability in the financial statements of zakat, infaq / alms / alms are analyzed based on PSAK 109 which consists of five components of financial statements namely financial position reports, changes in funds reports, assets under management, cash flow reports and financial statements

\footnotetext{
* Corresponding author.

E-mail addresses: Novanurl27@gmail.com (Novia Nurlailatul)
} 


\section{Pendahuluan}

Kemiskinan merupakan masalah yang sering terjadi terutama pada negara-negara berkembang seperti Indonesia. Saat ini pemerintah terus mencoba untuk meningkatkan kesejahteraan masyarakat miskin Indonesia khususnya dibidang ekonomi. Hal ini terlihat dari sistem perekonomian yang diterapkan oleh pemerintah yaitu, sistem ekonomi pancasila. Menurut Mubyarto (1987:32), sistem Ekonomi Pancasila merupakan sistem ekonomi yang dijiwai oleh ideologi Pancasila, yaitu sistem ekonomi yang merupakan usaha bersama berasaskan kekeluargaan dan kegotong-royongan nasional. Sistem ekonomi pancasila yang menjadi sumber ideologi Bangsa Indonesia yaitu Pancasila dijadikan dasar atau pedoman dalam kehidupan berbangsa dan bernegara. Meskipun demikian, sistem tersebut sampai saat ini belum berhasil dalam menangani permasalahan yang terjadi. Oleh karena itu, alternatif yang oleh banyak kalangan diyakini lebih menjanjikan adalah sistem ekonomi Islam, karena sistem ini berpijak pada asas keadilan dan kemanusiaan (Shahnaz, 2015). Untuk meningkatkan kesejahteraan, umat manusia menerapkan kepedulian sosial dengan memberikan sebuah media yang dikenal dengan sebutan "zakat, infak/ sedekah". Melalui media inilah Islam mengharuskan kepada umatnya yang sudah memenuhi standar untuk merealisasikan kepedulian sosialnya. Dalam penerapan tersebut dapat dilakukan oleh setiap lembaga yang bertujuan untuk mengurangi beban kemiskinan, salah satunya dengan cara memberikan bantuan kepada masyarakat yang membutuhkan. Bantuan tersebut disalurkan melalui suatu lembaga yaitu masjid.

Kaplale (2012) menjelaskan bahwa faktor-faktor penyebab kemiskinan adalah menurunnya produktifitas tanaman, lapangan kerja yang sulit diperoleh, rendahnya tingkat pendidikan kepala keluarga, ketergantungan masyarakat terhadap alam dan kondisi yang ada, biaya dalam proses ritual adat, serta terbatasnya akses terhadap modal (uang tunai). Suliswanto (2010) mengatakan bahwa permasalahan kemiskinan tidak cukup hanya dipecahkan melalui meningkatkan pertumbuhan ekonomi semata dengan mengharapkan terjadinya efek menetes ke bawah (trickle down effect). Akan tetapi, peningkatan kualitas Sumber Daya Manusia akan mampu memberikan pengaruh yang besar terhadap pengurangan angka kemiskinan yang terjadi. Agar manusia berkualitas dan beretika, manusia harus memiliki modal, yaitu pengetahuan dan kemampuan yang diperoleh melalui pendidikan, mulai dari program untuk anak-anak sampai dengan pelatihan dalam pekerjaan (on the job training) untuk para pekerja dewasa (Mankiw et al, 1992). Strategi pengentasan kemiskinan seharusnya tidak terpaku pada aspek ekonomi dan fisik saja, tetapi aspek nonfisik (rohaniah) juga perlu mendapatkan porsi yang cukup dalam kebijakan ini, dimana Pendidikan agama dan budi pekerti sangat penting untuk penanaman nilainilai agamawi dan budi pekerti terutama bagi anak-anak dan pemuda dalam menghadapi problematika kemiskinan di masa akan datang (Abrar, 2009) (Benazir, 2017).

Menurut Sadeli (2010:18) dalam Shahnaz (2015), laporan keuangan adalah laporan tertulis yang memberikan informasi kuantitatif tentang posisi keuangan beserta perubahan-perubahannya, serta hasil yang dicapai selama periode tertentu. Laporan keuangan juga dapat digunakan sebagai alat bantu bagi para pengguna didalam menilai kinerja perusahaan sehingga bisa mengambil suatu keputusan yang tepat. Praktek akuntansi pada lembaga nirlaba merupakan sesuatu yang jarang dilakukan dan kurang dipahami bagi para penyusun laporan keuangan. Sebaliknya, akuntansi merupakan bagian penting yang berpadu dengan kepentingan masjid guna meningkatkan dana dan manajemen keuangan yang baik untuk mencapai tujuan, (Irawati, 2005).

Laporan keuangan pada dasarnya adalah hasil dari proses akuntansi yang dapat digunakan sebagai alat komunikasi antara data keuangan atau aktivitas suatu perusahaan dengan pihak yang berkepentingan dengan data atau aktivitas dari perusahaan tersebut (Munawir, 2004: 2). Menurut Standar Akuntansi Keuangan PSAK No.1 (IAI, 2004: 04) mengemukakan "Laporan Keuangan merupakan laporan periodik yang disusun menurut prinsip-prinsip akuntansi yang diterima secara umum tentang status keuangan dari individu, sosiasi atau organisasi bisnis yang terdiri dari neraca, laporan laba rugi, laporan perubahan ekuitas, laporan arus kas dan catatan atas laporan keuangan (Trianto, 2017)

Laporan keuangan disiapkan oleh setiap perusahaan untuk dapat memberikan informasi yang berguna bagi para pemakai laporan, terutama untuk dijadikan sebagai dasar pertimbangan dalam proses pengambilan keputusan. Laporan keuangan merupakan produk akhir dari serangkaian proses pencatatan dan pengikhtisaran data transaksi bisnis, dimana seorang akuntan diharapkan mampu untuk mengorganisir seluruh data Akuntansi (Erica, 2018).

Menurut Pura (2013:86), laporan keuangan merupakan media komunikasi dan pertanggungjawaban antara perusahaan dan pemiliknya atau pihak lain yang mempunyai hubungan dengan perusahaan tersebut. Laporan Keuangan berperan sangat penting dalam suatu perusahaan, karena laporan keuangan tersebut akan memberikan informasi yang berkaitan dengan kondisi suatu 
perusahaan sehingga pihak-pihak berkepentingan terhadap informasi itu akan mengambil keputusan yang berhubungan dengan perusahaan tersebut (Zannati, 2016)

Laporan keuangan merupakan laporan tertulis yang memberikan informasi kuantitatif tentang posisi keuangan dan perubahan-perubahannya, serta hasil yang dicapai selama periode tertentu. Laporan keuangan dapat dijadikan media yang dapat dipakai untuk meneliti kondisi keuangan perusahaan, dimana laporan keuangan tersebut terdiri dari Neraca, Laporan Rugi/Laba atau hasil usaha, Laporan Arus Kas, dan Laporan Perubahan Posisi Keuangan. Harahap (2007: 105) mengatakan, Laporan Keuangan menggambarkan kondisi keuangan dan hasil usaha suatu perusahaan pada saat tertentu atau jangka waktu tertentu (Laila, 2017).

Surat Al-Baqarah ayat 282 menyampaikan bahwa Islam mendorong praktik untuk melakukan pencatatan akuntansi dalam kehidupan perdagangan (bermuamalah). Pada dasarnya, ilmu akuntansi dan praktek akuntansi di lingkungan muamalah telah menjadi bagian yang tidak terpisahkan (integral). Namun, ilmu akuntansi dan prakteknya diluar entitas muamalah khususnya lembaga keagaamaan masih jarang dilakukan. Sumber keuangan pada entitas didapat dari dana masyarakat yang berupa sumbangan, sedekah atau bentuk bantuan lainnya yang berasal dari masyarakat (publik). Semua kegiatan yang termasuk pada bagian entitas publik harus dipertanggung jawabkan kepada pihak eksternal. Transparansi dana dan akuntabilitas sebagai kata kunci pada entitas publik, sebagaimana firman Allah SWT dalam surat Al-Baqarah ayat 282:

"Hai orang-orang yang beriman, apabila kamu bermuamalah tidak secara tunai untuk waktu yang di tentukan, hendaklah seorang penulis diantara kamu menuliskannya dengan benar, dan janganlah penulis enggan menuliskannya sebagaimana Allah telah mengajarkannya".

Masjid At-Taqwa Tempurejo merupakan masjid yang berada di Kecamatan Tempurejo. Dimana lokasinya berada di Jl. Raya Untungsuropati RT 01 RW 05, Curahlele, Kecamatan Tempurejo, Kabupaten Jember. Masjid At-Taqwa Tempurejo berdiri sejak tahun 1975 dimana pada waktu itu masjid ini masih sangat sederhana dengan donatur yang masih sedikit dan bantuan yang diperoleh juga tidak terlalu besar. Seiring berjalannya waktu Masjid At-Taqwa Tempurejo ini semakin berkembang dan juga bertambahnya para donatur. Dimana sumber dana masjid berasal dari donasi maupun sumbangan, kotak amal masjid, infak, dan sedekah. Sumber dana tersebut diperoleh dari kegiatan masjid seperti sholat jum'at dan kegiatan lain pada hari besar Islam. Berdasarkan hasil wawancara pendahuluan dengan Ketua Takmir Masjid At-Taqwa Tempurejo diperoleh informasi bahwa dalam melakukan pencatatan masih dicatat secara manual dan sangat sederhana yang berupa penerimaan dan pengeluaran dana sehingga belum relevan dan andal. Hal ini akan berdampak kepada para donatur yaitu akan kehilangan kepercayaan sehingga mengakibatkan terjadinya penurunan sumber dana dari donatur. Karena belum relevan dan andal maka diperlukan adanya standar yang harus digunakan yaitu PSAK 109. Transparansi dan Akuntabilitas sangat diperlukan dalam penyusunan laporan keuangan agar dapat memberikan informasi yang relevan dan dapat diandalkan kepada donatur, penerima manfaat, dan publik (masyarakat). Sehingga para pengurus Masjid At-Taqwa Tempurejo secara tidak langsung dituntut untuk melakukan penyesuaian laporan keuangan yang formal sesuai dengan PSAK 109.

Dari latar belakang di atas, maka peneliti tertarik untuk melakukan penelitian tentang PSAK 109 pada laporan keuangan yang dilakukan Takmir Masjid At-Taqwa Tempurejo yang dituangkan dalam skripsi dengan judul, " Penerapan PSAK 109 Tentang Pelaporan Keuangan Akuntansi Zakat, Infak/Sedekah pada Masjid At-Taqwa Tempurejo".

Masjid berasal dari kata sajada yang artinya tempat sujud atau tunduk untuk menyembah Allah SWT. Sedangkan menurut istilah masjid merupakan tempat beribadah umat Islam atau Muslim kepada Allah SWT. Masjid bukan hanya sebagai tempat beribadah tetapi juga merupakan pusat kehidupan komunitas muslim. Masjid juga digunakan untuk kegiatan sosial lainnya seperti perayaan hari besar, diskusi, kajian agama, ceramah serta kegiatan-kegiatan lain yang bertujuan untuk mengembangkan masyarakat Islam (Alkaf.1990:440).

Dalam Al-Quran kata masjid terulang sebanyak dua puluh delapan kali baik secara tunggal maupun jamak. Dari segi bahasa, kata tersebut diambil dari akar kata sajada-sujud, yang berarti patuh, taat, serta dengan penuh hormat dan takzim.Sujud oleh syariat yaitu meletakkan dahi, kedua tangan, lutut dan kaki kebumi. Menurut Shihab (1996: 459), masjid dalam pengertiannya, merupakan rumah Allah SWT untuk melaksanakan shalat sebagai suatu kewajiban bagi seorang Muslim. Tetapi, karena akar katanya mengandung arti patuh dan tunduk, hakikat masjid adalah tempat untuk melakukan segala kegiatan yang bertujuan untuk patuh kepada Allah SWT semata.

Menurut Qadir (2001:62), ditinjau dari segi bahasa zakat berasal dari kata zaka yang bermakna $\mathrm{Al}$ Numulu (menumbuhkan), Al-Ziyadah (menambah), al barakah (memberkatkan) dan at-thahir (menyucikan). Menurut etimologi syari'at (Istilah) zakat adalah nama bagi sejumlah harta tertentu yang telah mecapai syariat tertentu yang diwajibkan Allah untuk dikeluarkan dan diberikan kepada orang- 
orang yang berhak menerimanya. Zakat adalah salah satu dari lima rukun Islam yang juga merupakan salah satu kewajiban yang mendasar dalam Islam, (Hafidhuddin, 2002). Tujuan utamanya adalah untuk mengembangkan pertumbuhan sosial ekonomi yang seimbang, dan untuk memurnikan jiwa dan kekayaan seseorang sehingga kekayaan mereka diridhoi oleh Allah SWT, (Hafidhuddin, 2002). Telah disebutkan dalam Al-Qur'an tentang zakat yang berbunyi :

“Ambillah zakat dari sebagian harta mereka, dengan zakat itu kamu membersihkan dan mensucikan mereka dan mendoalah untuk mereka. Sesungguhnya doa kamu itu (menjadi) ketenteraman jiwa bagi mereka. dan Allah maha mendengar lagi maha mengetahui. (QS,At-Taubah:103).

"Tidaklah mereka itu diperintahkan melainkan supaya beribadah kepada llah dengan ikhlas dan condong melakukan agama karenanya begitu pula supaya mengerjakan shalat dan mengeluarkan zakat dan itulah agama yang lurus"(QS.Al-Bayyinah:05)"

Zakat mempunyai beberapa karakteristik yang tercantum di dalam PSAK No.109 (IAI : 2011) yang menjelaskan beberapa macam karakteristik zakat sebagai berikut:

1. Zakat merupakan kewajiban syariah setiap umat muslim yang harus diserahkan oleh muzakki kepada mustahiq baik melalui amil maupun secara langsung. Ketentuan zakat mengatur mengenai persyaratan nisab, haul (baik yang periodik maupun yang tidak periodik), tarif zakat (qadar), dan peruntukannya.

2. Infak/sedekah merupakan donasi sukarela, baik ditentukan maupun tidak ditentukan peruntukannya oleh pemberi infak/sedekah.

3. Zakat dan infak/sedekah yang diterima oleh amil harus dikelola sesuai dengan prinsip-prinsip syariah dan tata kelola yang baik

Laporan keuangan adalah suatu informasi keuangan yang disajikan oleh perusahaan untuk para pengguna laporan keuangan dan sebagai bahan untuk pengambilan keputusan. Laporan keuangan disusun dan disajikan selama satu periode dengan tujuan untuk menggambarkan keadaan laporan keuangan perusahaan untuk memenuhi kebutuhan pihak internal maupun pihak eksternal perusahaan. Menurut Harahap (2008), laporan keuangan merupakan hasil akhir dari proses pencatatan akuntansi. Laporan ini yang menjadi bahan informasi bagi para pemakai baik pihak internal maupun eksternal sebagai salah satu bahan dalam proses pengambilan keputusan. Selain sebagai informasi laporan keuangan juga sebagai pertanggungjawaban atas tugas-tugas serta menggambarkan indikator kesuksesan suatu perusahaan untuk mencapai tujuannya. Suatu laporan keungan dibuat yang pastinya memiliki tujuan. Menurut Irham (2012:24) dalam Dewi Jilma (2017) tujuan laporan keuangan secara umum yaitu :

1. Untuk memberikan suatu informasi kepada pihak yang berkepentingan tentang kondisi perusahaan dari sudut angka dalam satuan moneter.

2. Menyediakan informasi yang bermanfaat bagi investor, kreditur, manajemen, pemerintah dan pengguna lainnya dalam pengambilan keputusan.

3. Menyediakan informasi yang berkaitan dengan posisi keuangan, kinerja dan perubahan posisi keuangan dalam suatu perusahaan dan bermanfaat bagi sejumlah pemakai laporan keuangan untuk pengambilan keputusan.

4. Memberikan sebuah informasi yang berkaitan dengan posisi keuangan, kinerja perusahaan, ekuitas, arus kas dan informasi yang lain.

Laporan keuangan harus disajikan secara akurat, detail, akuntabel dan transparan. Dalam kegiatannya semua transaksi dicatat dalam pembukuan untuk membuat laporan keuangan yang dapat diketahui oleh direktur kemudian laporan tersebut perlu dianalisis untuk dapat mengetahui keadaan, perkembangan dan kinerja keuangan dari tahun ke tahun. Dengan analisis ini dapat diketahui perkembangan usaha dari waktu yang lalu dan waktu yang berjalan (Susuanti, 2018).

Sedangkan didalam PSAK 109 (2011) bertujuan untuk mengatur pengakuan, pengukuran, penyajian dan pengungkapan transaski zakat, infaq/sedekah.

Pernyataan ini bertujuan untuk mengatur pengakuan, pengukuran, penyajian dan pengungkapan transaksi zakat, infaq dan shadaqah Perlakuan akuntansi dalam pembahasan ini mengacu pada PSAK 109, sehingga ruang lingkup PSAK ini hanya untuk amil zakat yang menerima dan menyalurkan zakat,infaq dan shadaqah,organisasi pengelola zakat yang pembentukannya dimaksudkan untuk mengumpulkan dan menyalurkan zakat (Sak Syariah,109.1).

Dalam PSAK No. 109 tentang akuntansi zakat, infaK/sedekah terdapat beberapa komponen laporan keuangan yang harus dibuat oleh amil secara lengkap yang terdiri dari: 1) Laporan Posisi Keuangan, 2) Laporan Perubahan Dana, 3) Laporan Perubahan Aset Kelolaan, 4) Laporan Arus Kas; dan 5) Catatan Atas Laporan Keuangan. 


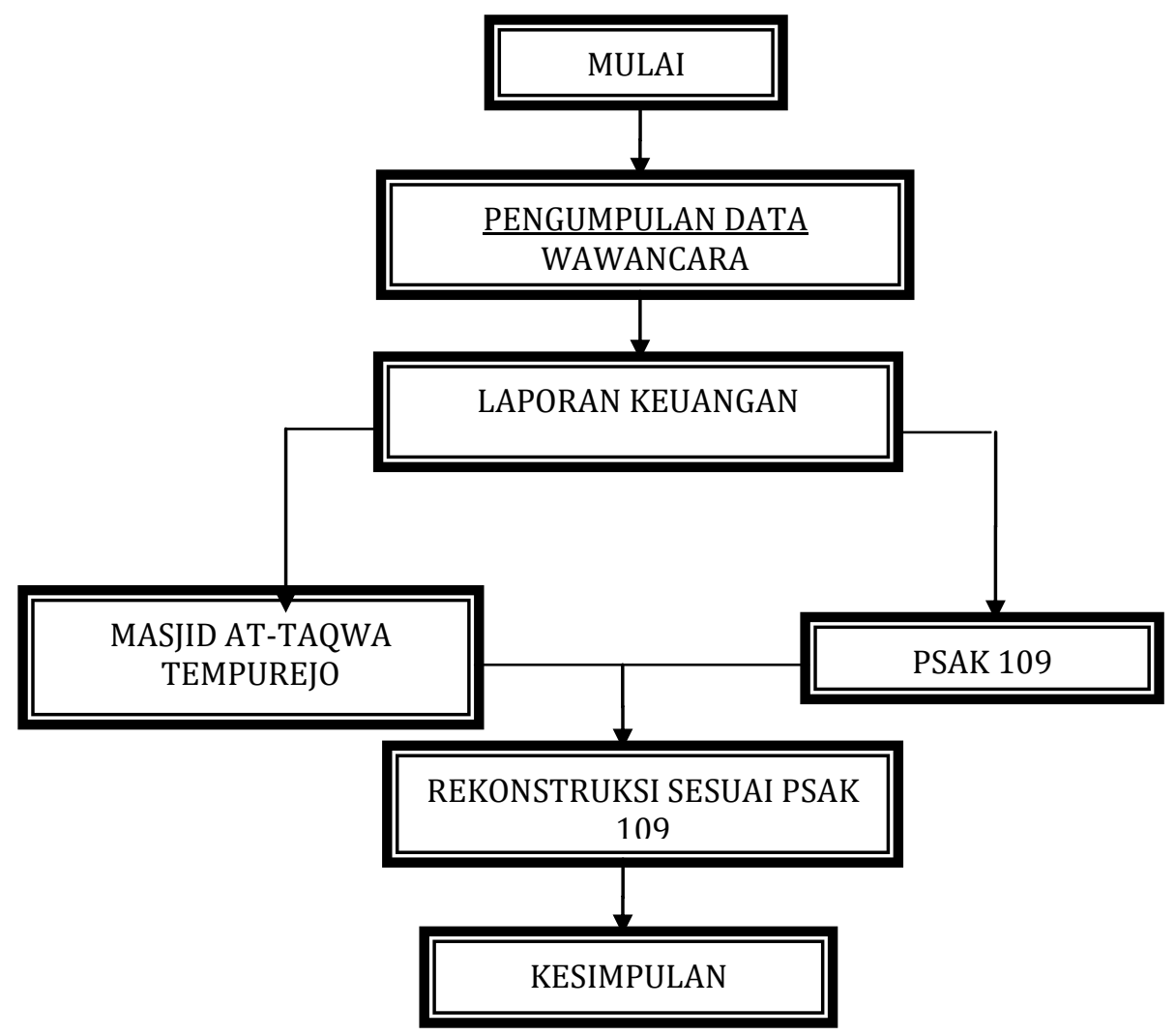

Gambar 1. Kerangka Pemecahan Masalah

\section{Metode}

Metodologi sebagaimana dikemukakan oleh Bogdan dan Taylor, (Soekanto,1986) merupakan proses, prinsip dan prosedur yang kita gunakan untuk mendekati problem dan mencari jawaban, pengertian ini menegaskan bahwa metodologi adalah suatu pendekatan umum untuk mengkaji masalah penelitian. Jenis penelitian yang digunakan dalam penelitian ini adalah penelitian deskriptif kualitatif yaitu metode yang sifatnya mengumpulkan, menguraikan, menggambarkan, membandingkan suatu data dan keadaan serta menerangkan suatu keadaan sedemikian rupa sehingga dapatlah ditarik suatu kesimpulan.

Pemilihan lokasi studi kasus di Masjid At-Taqwa Tempurejo ini di latarbelakangi oleh pelaporan keuangan masjid yang masih sangat sederhana, dimana semua uang itu dilaporkan dari hasil amal dan infak dari semua umat muslim yang berkunjung ke masjid ini. Lokasi penelitian yang dipilih sebagai studi kasus adalah Masjid At-Taqwa Tempurejo yang berada di Jl. Raya Untungsuropati RT 01 RW 05, Curahlele, Kecamatan Tempurejo, Kabupaten Jember

Jenis data yang digunakan dalam penelitian ini berupa data primer dan data sekunder yaitu:

\section{Data Primer}

Menurut Indriantoro dan Supomo (2009) dalam Yusuf (2014), data primer merupakan sumber data penelitian yang di peroleh secara langsung dari sumber asli (tidak melalui perantara) dan secara langsung melalui wawancara dan observasi. Dalam penelitian ini data primer berupa hasil wawancara dari sumber utama/responden.

2. Data sekunder

Data sekunder merupakan data penelitian yang diperoleh secara tidak langsung yang lebih dahulu dikumpulkan dan dilaporkan oleh diluar diri penyidik sendiri, walaupun yang di kumpulkan itu merupakan data asli (Winarno,1985:163). Dalam Penelitian ini data sekunder adalah data berupa laporan keuangan keuangan, dokumen-dokumen serta catatat-catatan yang ada di Masjid At-Taqwa Tempurejo.

Teknik Analisis Data yang digunakan terdapat 5 macam yang sesuai dengan pendapat moeleng yakni : Survei,Wawancara, Proses Akuntansi, Menganalisa kesesuaian dan Rekonstruksi. 


\section{Hasil dan pembahasan}

Laporan keuangan merupakan sebuah catatan informasi keuangan suatu perusahaan pada satu periode untuk memulai kinerja lembaga (IAI, 2011). Laporan keuangan yang sesuai dengan PSAK 109 yaitu terdiri dari Laporan Posisi Keuangan, Laporan Perubahan Dana, Laporan Perubahan Aset Kelolaan, Laporan Arus Kas dan Catatan Atas Laporan Keuangan.

Berikut merupakan cotnoh laporan keuangan yang sesuai dengan PSAK 109 Laporan Posisi Keuangan, Laporan Perubahan Dana, Laporan Perubahan Aset Kelolaan, Laporan Arus Kas dan Catatan Atas Laporan Keuangan pada Masjid At-Taqwa Tempurejo.

Tabel 1. Laporan Posisi Keuangan

\begin{tabular}{|c|c|c|c|}
\hline \multicolumn{4}{|c|}{$\begin{array}{l}\text { Masjid At-Taqwa Tempurejo } \\
\text { Laporan Posisi Keuangan } \\
\text { Per } 31 \text { Desember } 2018\end{array}$} \\
\hline Keterangan & $\mathbf{R p}$ & Keterangan & $\mathbf{R p}$ \\
\hline ASET & & LIABILITAS & \\
\hline Aset Lancar & & Liabilitas Jangka Pendek & - \\
\hline Kas & 4.591 .000 & Liabilitas Jangka Panjang & \\
\hline Rekening Bank BRI & 48.780 .000 & Jumlah Liabilitas & - \\
\hline JumlahAset Lancar & 53.371 .000 & $\begin{array}{l}\text { Saldo Dana } \\
\text { Saldo Dana }\end{array}$ & - \\
\hline Aset Tetap & & Dana Non Halal & \\
\hline Tanah & 558.500 .000 & & 1.149 .503 .500 \\
\hline Bangunan & 565.500 .000 & & 3.780 .000 \\
\hline Akm.Penyusutan & $(42.412 .500)$ & & \\
\hline Peralatan & 36.050 .000 & & \\
\hline Akm.Penyustuan & $(17.725 .000)$ & Jumlah Saldo Dana & \\
\hline Jumlah Aset Tetap & 1.099 .912 .500 & $\begin{array}{l}\text { Jumlah Liabilitas dan } \\
\text { Saldo Dana }\end{array}$ & 1.153 .283 .500 \\
\hline Jumlah Aset & 1.153.283.500 & & 1.153.283.500 \\
\hline
\end{tabular}

Tabel 2. Laporan Perubahan Dana

\begin{tabular}{lc}
\hline \multicolumn{1}{c}{$\begin{array}{c}\text { Masjid At-Taqwa Tempurejo } \\
\text { Laporan Perubahan Dana }\end{array}$} \\
& Untuk Tahun yang Berakhir Per 31 Desember 2018 \\
\hline $\begin{array}{l}\text { Keterangan } \\
\text { Saldo Awal } \\
\text { DANA ZAKAT }\end{array}$ & $\mathbf{1 6 . 4 5 3 . 0 0 0}$ \\
\hline $\begin{array}{l}\text { Penerimaan } \\
\text { Penerimaan dari muzakki }\end{array}$ & \\
Hasil Penempatan & 5.175 .000 \\
Jumlah Penerimaan dana zakat & - \\
\hline Penyaluran & $\mathbf{5 . 1 7 5 . 0 0 0}$ \\
Amil & \\
Fikir-Miskin & \\
Jumlah Penyaluran dana zakat & - \\
\hline
\end{tabular}

\section{DANA INFAK/SEDEKAH}

Penerimaaan

Infak/Sedekah tidak terikat atau muqayyadah

37.298 .000

Hasil pengelolaan 


\section{Penyaluran}

Amil

Operasional Lembaga

Jumlah penyaluran dan infak/sedekah

(4.160.000)

\section{DANA NON HALAL}

Bunga Bank

3.780 .000

Jasa Giro

Jumlah Penerimaan Dana Non Halal

3.780 .000

Jumlah saldo dana zakat, dana infak/sedekah, dan dana non halal

Tabel 3. Laporan Perubahan Asset Kelolaan

\section{Masjid At-Taqwa Tempurejo \\ Laporan Perubahan Dana}

Untuk Tahun yang Berakhir Per 31 Desember 2018

\begin{tabular}{|c|c|c|c|c|c|c|}
\hline \multirow[t]{2}{*}{ Keterangan } & \multirow{2}{*}{$\begin{array}{l}\text { Saldo } \\
\text { awal }\end{array}$} & \multicolumn{2}{|c|}{ Perubahan } & \multirow[t]{2}{*}{ Penyu } & \multirow[t]{2}{*}{ Akm. Penyu } & \multirow{2}{*}{$\begin{array}{l}\text { Saldo } \\
\text { akhir }\end{array}$} \\
\hline & & Penambahan & Pengurangan & & & \\
\hline $\begin{array}{l}\text { Aset Kelolaan } \\
\text { Lancar }\end{array}$ & - & - & $(\mathrm{xxx})$ & - & $(\mathrm{xxx})$ & $\mathrm{Xxx}$ \\
\hline $\begin{array}{l}\text { Aset Kelolaan } \\
\text { Tidak Lancar }\end{array}$ & - & - & $(\mathrm{xxx})$ & $(\mathrm{xxx})$ & - & $\mathrm{Xxx}$ \\
\hline
\end{tabular}

Tabel 4. Laporan Arus Kas

\begin{tabular}{lr}
\hline \multicolumn{1}{c}{$\begin{array}{c}\text { Masjid At-Taqwa Tempurejo } \\
\text { Laporan Arus Kas } \\
\text { Untuk Tahun yang Berakhir Per 31 Desember 2018 }\end{array}$} \\
$\begin{array}{lr}\text { Keterangan } \\
\text { Arus Kas Masuk dari Aktivitas Operasi : }\end{array}$ \\
$\begin{array}{l}\text { Aktivitas Operasi } \\
\text { Penerimaan dana zakat }\end{array}$ \\
Penerimaan dana infak/sedekah & 5.175 .000 \\
Penerimaan Non Halal & 37.298 .000 \\
Jumlah & 3.780 .000 \\
Arus Kas Keluar Dari Aktivitas Operasi & $\mathbf{4 6 . 2 5 3 . 0 0 0}$ \\
Operasional lembaga & \\
Zakat & \\
Jumlah & \\
Kenaikan atau Penurunan Kas & $(4.160 .000)$ \\
Saldo Kas Awal Tahun & $\mathbf{5 . 1 7 5 . 0 0 0 )}$ \\
Saldo Kas Akhir Tahun & $\mathbf{9 9 . 3 3 5 . 0 0 0 )}$ \\
\hline & $\mathbf{3 6 . 9 1 8 . 0 0 0}$ \\
& $\mathbf{1 6 . 4 5 3 . 0 0 0}$ \\
\hline
\end{tabular}


Tabel 5. Catatan Atas Laporan Keuangan Masjid At-Taqwa Tempurejo

1. Umum

Masjid At-Taqwa Tempurejo berada di jalan Raya Untungsuropati RT 01 RW 05 Kecamatan Tempurejo, Kabupaten Jember letaknya yang berada di pinggir jalan raya. Masjid At-Taqwa Tempurejo merupakan bangunan seluas $390 \mathrm{~m}^{2}$ yang berdiri diatas tanah wakaf bapak Dullah alias bapak Su'ya.

2. Visi Misi

a. Visi dari Masjid At-Taqwa Tempurejo adalah terwujudnya masjid yang makmur sebagai pusat beribadahan dan pemberdayaan umat islam.

b. Misi dari Masjid At-Taqwa Tempurejo adalah sebagai berikut :

i. Mengembangkan dakwah dan pembinaan umat melalui khutubah jumat dan kegiatankegiatan besar islami

ii. Mengembangkan kesejahteraan dan pemberdayaan umat, melalui kegiatan amil zakat, infak/sedekah.

Berdasarkan hasil penelitian yang telah dilakukan oleh peneliti pada Masjid At-Taqwa Tempurejo menunjukkan bahwa Masjid At-Taqwa Tempurejo belum menerapkan PSAK 109 tentang Akuntansi Zakat, Infak/Sedekah. Laporan keuangan yang disusun oleh pihak Masjid At-Taqwa Tempurejo yaitu hanya laporan penerimaan dan penyaluran dana zakat, infak/sedekah sehingga akan menghasilkan saldo. Pencatatan laporan penerimaan dana zakat, infak/sedekah pada Masjid At-Taqwa Tempurejo hanya berkaitan dengan dana yang masuk kepada bendahara Masjid At-Taqwa Tempurejo yang berasal dari kotak amal, sumbangan maupun zakat, sedangkan untuk pencatatan laporan penyaluran dana zakat , infak/sedekah hanya berkaitan dengan dana keluar yang digunakan untuk pembagian zakat dan kegiatan operasional Masjid At-Taqwa Tempurejo.

Dapat dilihat dari dari kondisi laporan keuangan yang telah dibuat oleh Takmir Masjid At-Taqwa Tempurejo diatas bahwasanya Masjid At-Taqwa Tempurejo sangat memerlukan suatu penyusunan laporan laporan keuangan yang baik dan sesuai dengan standar pelaporan keuangan. Maka dari itu nantinya laporan yang telah disusun akan mencerminkan aktivitas operasi pada Masjid At-Taqwa Tempurejo yang sebenar-benarnya dan laporan keuangan yang disusun lebih mudah dipahami oleh para pengguna laporan keuangan, baik pihak Takmir Masjid At-Taqwa Tempurejo maupun bagi para donatur dan penyumbang, serta memeberikan gambaran dimasa yang akan datang.

Penyusunan laporan keuangan yang sesuai dengan standar akuntansi di Indonesia yaitu PSAK 109 tentang Akuntansi Zakat, Infak/Sedekah, maka untuk itu peneliti menerapkan laporan keuangan yang sesuai dengan standar berdasarkan transaksi ataupun data yang diperoleh dan didapatkan dari hasil pengamatan terhadap objek penelitian yaitu Masjid At-Taqwa Tempurejo baik secara langsung maupun tidak langsung.

Bila dilihat dari pencatatan maka laporan keuangan zakat, infak/sedekah masjid At-Taqwa Tempurejo tidak sesuai dengan standar PSAK 109. Sehingga dapat disimpulkan bahwa laporan keuangan zakat, infak/sedekah pada Masjid At-Taqawa Tempurejo ini harus memakai dan menerapkan satndar laporan keuangan yang telah ditetapkan yakni PSAK No. 109 tentang Zakat, Infak/Sedekah, seperti yang telah disebutkan pada Exposure Draft PSAK 109 disebutkan bahwa sumber dana yang diperoleh berasal dari dana zakat, infak/sedekah, dana non halal dan dana amil.

Laporan keuaangan zakat, infak/sedekah yang dibuat oleh takomir masjid At-Taqwa Tempurejo sejauh ini masih berupa catatan-catatan penerimaan dan pengeluaran dana dan masih belum membuat laporan keuangan zakat, infak/sedekah yang lengkap sesuai dengan yang tertuang didalam PSAK 109. Masjid At-Taqwa Tempurejo masih membuat satu komponen laporan keuangan yaakni hanyaa berupa catatan aliran dana masuk dan aliran dana keluar, hal ini dikarenakan masjid At-Taqwa Tempurejo tidak memiliki tenaga ahli dalam bidang akuntansi. Dalam pembuatan laporan keuangan masjid At-Taqwa Tempurejo masih menggunakan kebijakan sendiri dan tidak menegarah pada pedoman apapun.

Laporan keuangan zakat,infak/sedekah masjid At-Taqwa Tempurejo yang masih sangat sederhana yakni hanya berupa penerimaan dan pengeluaran dana dan belum sesuai dengan standar yang berlaku yaitu PSAK 109. Karena itu peneliti merekomendasikan kepada takmir masjid At-Taqwa Tempurejo untuk membuat laporan keuangan zakat, infak/sedekah sesuai dengan PSAK 109 yang terdiri dari lima komponen laporan keuangan yaitu Laporan Posisi Keuangan, Laporan Perubahan Dana, Laporan Perubahan Asset Kelolaan, Laporan Arus Kas dan Catatan Atas Laporan Keuangan. 


\section{Simpulan dan saran}

Berdasarkan hasil penelitian dan pembahasan pada bab sebelumnya, dihasilkan kesimpulan bahwa bentuk laporan keuangan Zakat, Infak/Sedekah pada Masjid At-Taqwa Tempurejo belum sesuai dengan standar yang berlaku yaitu PSAK 109, dimana laporan keuangan masjid masih sangat sederhana, yaitu hanya terdiri dari penerimaan dan pengeluaran sehingga akan menghasilkan saldo akhir. Seharusnya laporan keuangan Masjid At-Taqwa Tempurejo disesuaikan dengan standar yang berlaku yaitu PSAK 109 . Masjid At-Taqwa Tempurejo belum membuat laporan keuangan zakat, infak/sedekah berdasarkan PSAK 109 maka peneliti melakukan rekonstruksi pada laporan keuangan zakat, infak/sedekah berdasarkan data-data yang dimiliki oleh masjid At-Taqwa Tempurejo. Penerapan laporan keuangan zakat, infak/sedekah pada masjid berdasarkan PSAK 109 terdiri dari lima komponen yaitu Laporan Posisi Keuangan, Laporan Perubahan Dana, Laporan Perubahan Asset Kelolaan, Laporan Arus Kas dan Catatan Atas Laporan Keuangan.

Setelah melakukan penelitian terhadap laporan keuangan masjid At-Taqwa Tempurejo maka disajikan beberapa saran untuk para Takmir masjid At-Taqwa Tempurejo yakni sebaiknya bentuk laporan keuangan zakat, infak/sedekah pada Masjid At-Taqwa Tempurejo pada masa yang akan datang sesuai dengan standar yang berlaku yaitu PSAK 109 dan rekonstruksi yang telah dilakukan oleh peneliti diharapkan supaya bisa menjadi bahan acuan untuk pembelajaran bagi para takmir dan pengurus masjid At-Taqwa Tempurejo dalam mencatat laporan keuagan zakat, infak/sedekah.

\section{Daftar Rujukan}

Al-Quran dan Terjemahannya,( 2013). Pustaka Al-Mubin. Jakarta

Andarsari, P. R. (2016). Laporan Keuangan Organisasi Nirlaba (lembaga masjid). EKONIKA: Jurnal Ekonomi Universitas Kadiri, 1(2).

Benazir. (2017). Analisis Faktor-Faktor yang Mempengaruhi Kemiskinan di Kabupaten Pidie Jaya . Jurnal Fakultas Ekonomi dan Bisnis, UIN Ar-Raniry, Darussalam, Banda Aceh, 23111, Indonesia

Devi. (2014). Penerepan PSAK 109 tentang Akuntansi Zakat, Infak/Sedekah pada BAZ Kota Pekanbaru. Riau

Erica, Denny. (2018). Analisa Rasio Laporan Keuangan Untuk Menilai Kinerja Perusahaan PT Kino Indonesia Tbk . Jurnal Ecodemica, Vol. 2 No. 1 April 2018

Ikatan Akuntansi Indonesia. (2010).Standar Akuntansi Keuangan Zakat dan Infak/Sedekah. Dewan Standar Akuntansi Syariah, Jakarta.

Ikatan Akuntansi Indonesia. (2014). Standar Akuntansi Keuangan tentang Pelaporan Keuangan Organisasi Nirlaba. Dewan Standar Akuntansi Syariah, Jakarta.

Laila, Noor. (2017). Analisis Laporan Keuangan Sebagai Alat Untuk Mengevaluasi Kinerja Keuangan Pada Pt Wijaya Karya (Persero) Tbk Dan Pt Waskita Karya ( Persero) Tbk . eJournal Administrasi Bisnis, 2017, 5 (3): 577-588 ISSN 2355-5408, ejournal.adbisnis.fisip-unmul.ac.id

Nariasih, D. Y., Kurrohman, T., \& Andriana, A. Laporan Keuangan Masjid Berdasarkan Kombinasi PSAK Nomor 45 dan PSAK Nomor 109 (Studi Kasus Pada Masjid XYZ)(Financial Statement of Mosque Based on A Combination of PSAK Number 45 and PSAK Number 109 (A Case Study on XYZ Mosque)).

Shahnaz, S. (2016). Penerapan PSAK No. 109 tentang Pelaporan Keuangan Akuntansi Zakat, Infaq/Sedekah pada Badan Amil Zakat Provinsi Sulawesi Utara. Jurnal EMBA: Jurnal Riset Ekonomi, Manajemen, Bisnis dan Akuntansi, 3(4).

Susianti, Ina. (2018). Analisis Laporan Keuangan Untuk Menilai Kinerja Keuangan Pada Pt. Gudang Garam Tbk. Pada Periode 2013 - 2015 . Jurnal Simki-Economic Vol. 02 No. 02 Tahun 2018 ISSN : 25990748 
Trisnawati, D. M. F. (2015). Penerapan PSAK 109 Tentang Akuntansi Zakat dan Infak/Sedekah pada BAZ Kota Pekanbaru. Kutubkhanah, 17(1), 40-59.

Trianto, Anton. (2017). Analisis Laporan Keuangan Sebagai Alat Untuk Menilai Kinerja Keuangan Perusahaan Pada Pt. Bukit Asam (Persero) Tbk Tanjung Enim . Jurnal Ilmiah Ekonomi Global Masa Kini Volume 8 No.03 Desember 2017 Issn Print : 2089-6018 Issn Online : 2502-2024.

Zannati, Rachma. (2016). Analisis Laporan Keuangan Pt. Gatari Sebagai Dasar Pertimbangan Pemberian Kredit Modal Kerja Pada Pt.Bank Dki . Jurnal Riset Manajemen dan Bisnis Vol.1, No.2,Oktober 2016 : 81 - 92 ISSN 2527 - 7502 